\title{
Audit Kepatuhan Terpadu dalam Pencegahan Kebakaran Hutan dan Lahan
}

\author{
Oleh : Lakso Anindito ${ }^{1}$
}

\begin{abstract}
Abstrak
Pelaksanaan audit kepatuhan terpadu memiliki peran yang strategis dalam memetakan akar permasalahan, memastikan pelaksanaan kewajiban dan mendukung proses penegakan hukum khususnya hukum adminsitratif dalam mencegah kebakaran hutan dan lahan. Persoalannya, sampai saat ini, pendekatan audit kepatuhan secara terpadu belum dilakukan dan dimanfaatkan secara optimal oleh pemerintah karena perpindahan kepemimpinan pada tingkat nasional. Untuk itu, tulisan ini akan membahas beberapa aspek. Pertama, tulisan ini akan membahas peranan audit kepatuhan terpadu sebagai inovasi. Kedua, penggunaan konsep pertanggungjawaban korporasi dalam hal kepatuhan pencegahan kebakaran hutan dan lahan sebagai landasan dalam menentukan ukuran kepatuhan dalam pelaksanaan audit kepatuhan terpadu. Ketiga, kewenangan pemerintah dalam pelaksanaan audit kepatuhan terpadu. Keempat, prasyarat efektivitas pelaksanaan audit kepatuhan. Berdasarkan aspek-aspek maka dapat disimpulkan bahwa apabila audit kepatuhan terpadu dilaksanakan dengan memenuhi perasyarat maka dapat menjadi perangkat efektif dalam mencegah kebakaran hutan dan lahan.
\end{abstract}

Kata Kunci: Audit Kepatuhan Terpadu, Teori Kebijakan Pencegahan (prevention policy theory), Kepatuhan, Penegakan Hukum Administrasi, Kebakaran Hutan dan Lahan

1 Penulis merupakan pegiat dibidang penegakan hukum yang menjadi tim audit kepatuhan dalam rangka pencegahan kebakaran hutan dan lahan tahun 2014. Pernah bekerja di Satuan Tugas Presiden Pemberantasan Mafia Hukum, Satuan Tugas Presiden Persiapan Kelembagaan REDD+ dan Badan Pengelola REDD+. Mempunyai ketertarikan diisu penegakan hukum, sumber daya alam dan pertanggungjawaban pidana korporasi. 


\begin{abstract}
Based on the theory of prevention policy, audit compliance has an important role as instrument to prevent haze pollution that is caused by forest and land fires. This approach is potentially used by the government to find roots of the problem of haze pollution related with forest and land fires, to encourage compliance of object of audit and to get early information and data for administrative law enforcement. In this paper, audit compliance is elaborated in four aspects comprehensively. Firstly, the role of audit compliance as instrument of prevention policy. Secondly, corporate liability and compliance standard to prevent forest and land fires. Thirdly, legal basis of government to conduct audit compliance. Finally, the prerequisites to conduct audit compliance effectively. In conclusion, the audit compliance program has strategist function as an instrument to prevent forest and land fires based on prevention policy theory as long as the prerequisite are fulfilled.
\end{abstract}

Key Words: Compliance Audit, Prevention Policy Theory, Compliance, Administrative Enforcement, Land and Forest Fire.

\title{
I. Pendahuluan
}

Secara umum audit kepatuhan lingkungan hidup (environmental auditing) didefinisikan sebagai:

"Environmental auditing is essentially an environmental management tool for measuring the effects of certain activities on the environment against set criteria or standards." 2

Definisi tersebut berbeda dengan analisis dampak lingkungan (environmental impact assessment) yang dilakukan sebelum kegiatan usaha terlaksana dan berisi perkiraan dampak dari kegiatan tersebut. ${ }^{3}$ Pelaksanaan audit kepatuhan tersebut dapat dilakukan oleh pemerintah secara langsung, seperti program audit kepatuhan yang dilakukan oleh Environmental Protection Authority (EPA) Australia terhadap kegiatan industri dengan resiko tinggi yang ditentukan oleh

2 https://www.soas.ac.uk/cedep-demos/000 P508 EAEMS K3736-Demo/unit1/page 14. $\underline{\mathrm{htm}}$ diakses pada 24 Juli 2017

3 https://www.soas.ac.uk/cedep-demos/000 P508 EAEMS K3736-Demo/unit1/page 14. $\underline{\mathrm{htm}}$ diakses pada 24 Juli 2017 
pemerintah. ${ }^{4}$ Selain itu, audit kepatuhan juga dapat dilakukan secara mandiri oleh korporasi baik dengan menunjuk pihak ketiga ataupun dilakukan sendiri oleh korporasi dengan standar pelaksanaan yang sudah ditentukan oleh pemerintah sebagaimana diterapkan oleh Environmental Protection Agency (EPA) di Amerika Serikat. ${ }^{5}$ Pada bidang lain, pedoman untuk melakukan audit mandiri dilakukan pula di Inggris dalam pencegahan tindak pidana korupsi sebagaimana diterapkan sesuai pedoman prinsip-prinsip adequate procedure yang bahkan dapat digunakan sebagai pembelaan ketika tindak pidana terjadi. ${ }^{6}$

Pada perkembangannya, di Indonesia, mewacana konsep audit kepatuhan terpadu yang secara tujuan mirip dengan audit kepatuhan lingkungan hidup (environmental auditing). Secara definisi, audit kepatuhan terpadu adalah audit yang dilakukan oleh pemerintah melalui tim terpadu lintas kementerian/lembaga serta ahli dalam rangka mendapatkan gambaran secara menyeluruh tingkat kepatuhan objek audit. Berdasarkan pelaksanaan yang pernah dilakukan, objek dari audit kepatuhan tersebut dapat dilakukan terhadap korporasi maupun pemerintah daerah. $^{7}$ Tulisan ini akan memfokuskan pembahasan pada audit kepatuhan terpadu dalam pencegahan kebakaran hutan dan lahan yang selanjutnya disebut sebagai audit kepatuhan terpadu.

Berdasarkan objek maupun pelaksana, audit kepatuhan terpadu berbeda dengan konsep audit lingkungan hidup yang dilaksanakan oleh auditor lingkungan hidup dengan objek korporasi sebagaimana diatur dalam UndangUndang tentang Perlindungan dan Pengelolaan Lingkungan Hidup (UU PPLH). ${ }^{8}$ Akan tetapi, secara prinsip, audit kepatuhan terpadu dan audit lingkungan hidup memiliki tujuan yang sama karena dilakukan pada saat korporasi tersebut telah beraktivitas (ex post) bukan sebelum aktivitas dilakukan (ex ante). ${ }^{9}$

4 Sophie Martin, Epa Industry Compliance Audit Report For The Surface Coating Sector, (Adelaide: EPA, 2008), hlm. 1-3

5 https://www.epa.gov/compliance/audit-protocols diakses pada tanggal 8 Juni 2017

6 Adequate procedure adalah 6 (enam) prinsip pencegahan yang wajib dilaksanakan oleh korporasi dalam mencegah korupsi. Lihat : Nicholls QC, Colin et al., Corruption and Misuse of Public Office: Second Edition, (Oxford: Oxford University Press, 2011), hlm. 89

7 Tim Audit Kepatuhan Terpadu, Ringkasan Eksekutif (Executive Summary) Audit Kepatuhan Dalam Rangka Pencegahan Kebakaran Hutan Dan Lahan Di Provinsi Riau, (Jakarta: BP REDD+, 2014), hlm. 4-5

8 Indonesia (a), Undang-Undang tentang Perlindungan dan Pengelolaan Lingkungan Hidup, UU No. 32 Tahun 2009, LN No. 140 Tahun 2009, TLN No. 5059, ps. 49 - 51.

$9 \quad$ Ibid., ps. 1 angka 28. 
Untuk mendalami hal tersebut, tulisan ini akan menggunakan pendekatan Teori Kebijakan Pencegahan (prevention policy theory) yang dikembangkan oleh Ian Gough dalam menguji peranan audit kepatuhan terpadu sebagai upaya intervensi pemerintah dalam melakukan pencegahan. Sedangkan, pada lingkup yang lebih detail yang melihat audit kepatuhan terpadu sebagai bagian dari penegakan hukum administrasi untuk mendorong kepatuhan, digunakan pendekatan Albert J. Reiss jr.

\section{Peranan Audit Kepatuhan Terpadu}

Keberhasilan pencegahan kebakaran hutan dan lahan merupakan tujuan utama dari dilakukannya audit kepatuhan terpadu. Untuk dapat mengukur peranan dari audit kepatuhan terpadu tersebut dalam mencegah kebakaran hutan dan lahan, diperlukan adanya pemahaman yang sama mengenai ukuran pencegahan. Menurut Ian Gough pencegahan tidak dapat ditafsirkan secara langsung sesuai definisi yang ada dalam kamus yang membatasi hanya pada menghentikan sesuatu sehingga tidak terjadi. Akan tetapi, harus dilihat dari konteks tujuan dilakukannya pencegahan yang didasarkan pada kondisi faktual sesuatu yang harus dicegah dan dalam tahapan apa pencegahan tersebut dilakukan. ${ }^{10}$ Pada konteks tersebut, pencegahan dapat dibagi dalam tiga tahap, yaitu: pencegahan dalam konteks primer, sekunder dan tersier. Primer adalah tujuan utama dari pencegahan sebelum terjadi. Sekunder adalah upaya mitigasi efek dari hal yang sudah terjadi khususnya pada kelompok tertentu. Sedangkan, tersier adalah mencegah dampak yang lebih besar dari dampak yang tidak mungkin dihindari (Lihat Tabel 1). ${ }^{11}$

10 Ian Gough (a), Understanding prevention policy: A theoretical approach, (London:LSE, 2013), hlm. 2 
Table 1: Varying definitions of primary, secondary and tertiary forms of prevention

\begin{tabular}{|c|c|c|c|}
\hline & Primary & Secondary: & Tertiary \\
\hline General (Coote 2012 & $\begin{array}{l}\text { 'Upstream': Prevent harm before } \\
\text { it occurs, usually focusing on } \\
\text { whole populations and systems }\end{array}$ & $\begin{array}{l}\text { 'Midstream': Mitigate the } \\
\text { effects of harm that has } \\
\text { already happened; focus on } \\
\text { groups at risk }\end{array}$ & $\begin{array}{l}\text { 'Downstream': Cope with } \\
\text { the consequences of } \\
\text { harm, stop things from } \\
\text { getting worse }\end{array}$ \\
\hline $\begin{array}{l}\text { World Bank: Social risk } \\
\text { management (Holzmann and } \\
\text { Jorgensen 2001:541-2 }\end{array}$ & $\begin{array}{l}\text { Prevention: reduce the probability } \\
\text { of a downside risk }\end{array}$ & $\begin{array}{l}\text { Mitigation: reduce the } \\
\text { potential impact of a future } \\
\text { down-side risk }\end{array}$ & $\begin{array}{l}\text { Coping: Relieve the } \\
\text { impact of the risk once it } \\
\text { has occurred }\end{array}$ \\
\hline $\begin{array}{l}\text { Health (OECD 2009; NPHP } \\
\text { 2006) }\end{array}$ & $\begin{array}{l}\text { Prevent the onset of undesirable } \\
\text { states }\end{array}$ & $\begin{array}{l}\text { Early stage disease detection } \\
\text { and interventions }\end{array}$ & $\begin{array}{l}\text { Minimise impact of } \\
\text { disease }\end{array}$ \\
\hline $\begin{array}{l}\text { Crime (Brantigham and Faust } \\
\text { 1976) }\end{array}$ & $\begin{array}{l}\text { Reduce crime events by modify } \\
\text { the physical and/or social } \\
\text { environment }\end{array}$ & $\begin{array}{l}\text { Identify at risk populations } \\
\text { and potential criminals and } \\
\text { address the causal risk factors }\end{array}$ & $\begin{array}{l}\text { Stop criminals committing } \\
\text { more crime, eg via } \\
\text { imprisonment }\end{array}$ \\
\hline $\begin{array}{l}\text { Social work (Hardiker et al } \\
\text { 1991) }\end{array}$ & $\begin{array}{l}\text { Prevent the emergence of a } \\
\text { problem }\end{array}$ & $\begin{array}{l}\text { Early identification of } \\
\text { problem; amelioration and } \\
\text { containment of serious } \\
\text { problems }\end{array}$ & $\begin{array}{l}\text { Avoid further harm to } \\
\text { client }\end{array}$ \\
\hline
\end{tabular}

Sesuai dengan tabel tersebut, perlu dilakukan pendalaman untuk melihat posisi audit kepatuhan terpadu dalam tahapan pencegahan kebakaran hutan dan lahan (primer, sekunder dan tersier). ${ }^{12}$ Pada level primer, perlu diuji apakah audit kepatuhan terpadu dapat mencegah kejahatan dengan memodifikasi keadaan fisik dan/atau lingkungan sosial sehingga kebakaran dapat dicegah sebelum terjadi. Pada konteks sekunder, pada kondisi faktual kebakaran hutan dan lahan yang pasti terjadi disetiap tahunnya dengan tingkat luas kebakaran berbeda-beda, apakah audit kepatuhan terpadu mampu mengindentifikasi resiko serta menganalisis faktor-faktor penyebabnya sehingga pencegahan dapat dilakukan dalam konteks mitigasi untuk mencegah dampak. Pendekatan sekunder biasanya digunakan pada konteks kondisi yang sedang terjadi tetapi untuk menghidari dampak, seperti perubahan iklim yang sedang terjadi sehingga dapat dilakukan langkah-langkah pencegahan segera agar tidak terjadi secara meluas. ${ }^{13}$ Pada level tersier, apakah audit kepatuhan dapat menghentikan dampak yang saat pencegahan dilakukan sudah terjadi dan dampaknya tidak mungkin dihindari. Sebagai contoh: kebakaran sedang terjadi secara meluas. Untuk melihat posisi dan peranan audit kepatuhan terpadu melalui pendekatan tersebut, maka perlu dilihat pelaksanaan audit kepatuhan terpadu yang sudah pernah dilakukan baik pada tataran pelaksanaan maupun konsep yang melandasi pelaksanaan audit kepatuhan.

12 Anna Coote menggunakan istilah Upstream, Midstream dan Downstream, silahkan lihat A Coote, The Wisdom of Prevention (London: nef, 2012) hlm.9-11

13 Ian Gough (b), Climate Change and Public Policy Futures, A Report Prepared for the British Academy, (London : The British Academy, 2011) hlm. 31-34 
Pada tahun 2014, pemerintah melakukan audit kepatuhan terpadu sebagai salah satu langkah melakukan pencegahan kebakaran hutan dan lahan. Audit kepatuhan terpadu tersebut dilakukan oleh tim lintas Kementerian/Lembaga yang terdiri dari Unit Kerja Presiden Bidang Pengawasan dan Pengendalian Pembangunan (UKP-PPP), Badan Pengelola Penurunan Emisi Gas Rumah Kaca Dari Deforestasi, Degradasi Hutan dan Lahan Gambut (BP REDD+), Kementerian Kehutanan, Kementerian Pertanian dan Kementerian Lingkungan Hidup. ${ }^{14}$ Pelaksanaan audit kepatuhan tersebut didukung pula oleh Kepolisian, Kejaksaan dan Pemerintah Daerah yang memberikan askes data, informasi dan pengamanan saat dibutuhkan. Melalui pelaksanaan audit kepatuhan tersebut, terdapat beberapa manfaat pelaksanaan audit kepatuhan terpadu tersebut dalam mencegah kebakaran hutan dan lahan dihubungkan dengan pencegahan dalam tahap primer, sekunder dan tersier.

Pertama, mengukur kepatuhan objek audit dalam pencegahan kebakaran hutan dan lahan. Secara konsep, pelaksanaan audit kepatuhan terpadu berperan penting untuk mengukur apakah perusahaan dan pemerintah daerah sudah melakukan upaya optimal dalam pencegahan kebakaran hutan dan lahan. Pengetahuan tingkat kepatuhan tersebut dapat ditindaklanjuti dengan mendorong perusahaan untuk melakukan upaya segera sebelum kondisi rawan kebakaran baik yang diakibatkan dari kondisi alam, seperti: keadaan cuaca yang mendorong mudahnya terjadi kebakaran, ${ }^{15}$ maupun diakibatkan kondisi bukan alam, seperti: musim tanam. Kondisi rawan tersebut menjadikan kebakaran hutan dan lahan mempunyai kemungkinan yang tinggi untuk terjadi setiap tahunnya. ${ }^{16}$ Untuk itu, data dan informasi memiliki fungsi penting untuk mencegah agar tidak terjadi dengan skala meluas dan masif dengan berhasilnya dilakukan pemetaan data dan informasi pada objek tertentu sebagai bahan intervensi pemerintah.

Tujuan audit kepatuhan untuk memperoleh informasi dan data terkait kepatuhan korporasi dilakukan pula di negara lain, sebagai contoh adalah salah satu dari tujuan pelaksanaan audit kepatuhan di New South West, Australia, yaitu:

14 Tim Audit Kepatuhan Terpadu, Ringkasan Eksekutif... (n6) hlm. 3-5

15 Lihat https://www.lapan.go.id/index.php/subblog/read/2014/838/KEKERINGAN-TAHUN-2014-NORMAL-ATAUKAH-EKSTRIM/1653 diakses pada tanggal 3 Agustus 2017

16 Andrew P. Vadya, Explaining Indonesian Forest Fires: Both Ends of the Firestick dalam D.G. Bates and J. Tucker (eds.), Human Ecology: Contemporary Research and Practice, (NY, Spinger, 2010) hlm. 19 
“...improving compliance with legislative requirements..., ensuring that statutory instruments are robust and are appropriately used to achieve desired environmental and conservation outcomes..."17

Secara praktek, hasil pelaksanaan audit kepatuhan terpadu pada tahun 2014 yang mampu menggambarkan tingkat kepatuhan kegiatan usaha pada 17 (tujuh belas) konsesi yang dimiliki 15 (lima belas) korporasi yang pernah terdeteksi terdapat kebakaran diwilayahnya. (lihat Diagram 1 dan Diagram 2).

\section{Diagram 1. Hasil Penilaian Tingkat Kepatuhan Perusahaan di 5 (lima) konsesi} Perkebunan Dalam Rangka Pencegahan Kebakaran Hutan dan Lahan ${ }^{18}$

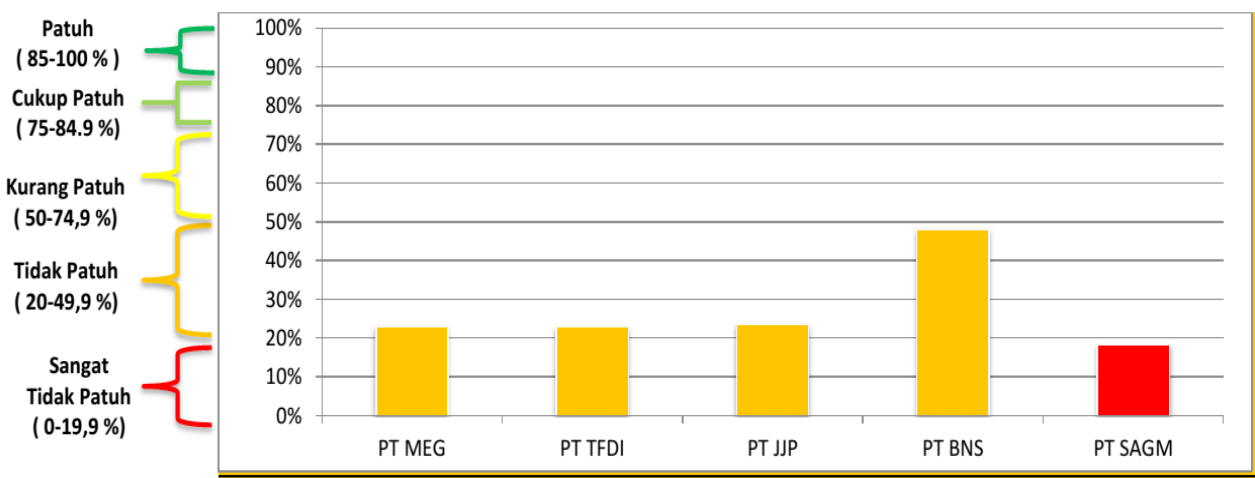

Diagram 2. Hasil Penilaian Tingkat Kepatuhan Perusahaan Kehutanan di 12 (dua belas) Konsesi Korporasi Dalam Rangka Pencegahan Kebakaran Hutan dan Lahan

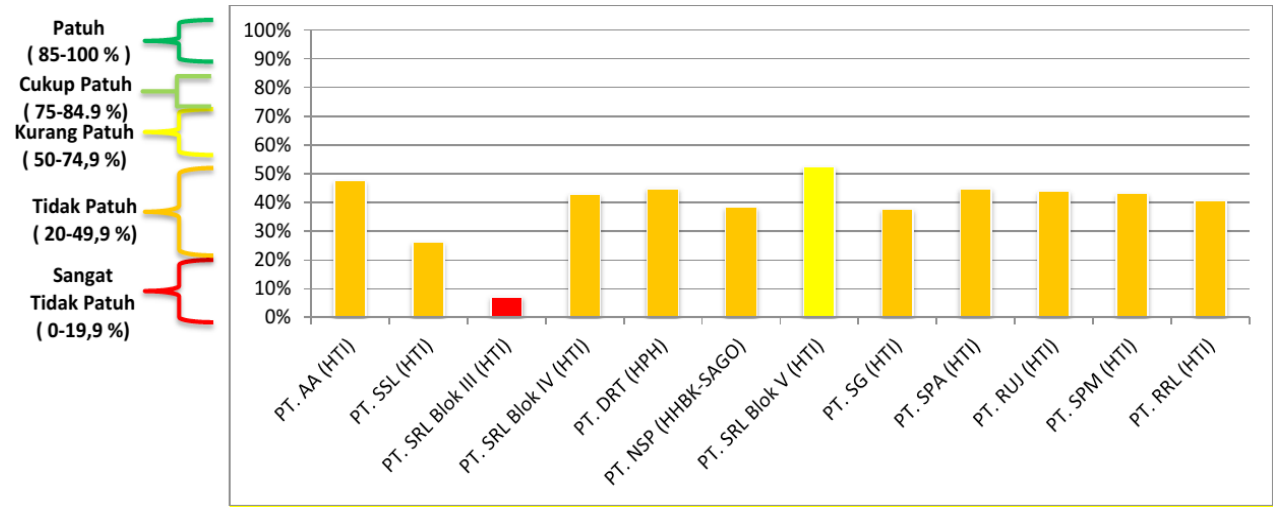

17 Departement of Environment and Conservation Team, Audit Compliance Handbook, (NSW: DEC, 2006). Hlm. 1-2

18 Tim Audit Kepatuhan Terpadu, Ringkasan Eksekutif... (n6) Hlm. 5-6 
Pelaksaaan audit kepatuhan terpadu tersebut menunjukan bahwa seluruh perusahaan baik perkebunan dan kehutanan belum memenuhi standar minimal dalam pencegahan kebakaran hutan dan lahan. ${ }^{19}$ Melalui pengukuran tersebut maka tim terpadu dapat melakukan indentifikasi kewajiban yang harus dilakukan oleh perusahaan secara mendetail masing-masing perusahaan yang harus dipenuhi dalam jangka waktu tertentu. ${ }^{20}$

Data dan informasi tersebut penting untuk mencegah terjadinya kejahatan dengan memotong salah satu penyebab terjadinya kebakaran hutan dan lahan secara sistematis serta meluas dengan memastikan kepatuhan korporasi. Sesuai dengan salah satu elemen penting dalam teori pencegahan adalah dengan mencegah salah satu penyebab kejahatan tersebut dilakukan. ${ }^{21}$

Kedua, penegakan hukum administrasi. Data dan informasi yang didapat dari audit kepatuhan terpadu dapat digunakan sebagai informasi awal bagi pemerintah daerah maupun Kementerian Lingkungan Hidup dan Kehutanan untuk melaksanakan penegakan hukum administrasi apabila diperlukan untuk mencegah kebakaran hutan dan lahan. Kewenangan tersebut sebagai bagian dari lingkup pengawasan untuk memastikan korporasi melakukan kewajibannya sesuai rekomendasi. ${ }^{22}$

Melalui penegakan hukum adminsitrasi tersebut maka dapat dipastikan ketaatan korporasi untuk menindaklanjuti hasil temuan tim terpadu sebelum tindak pidana terjadi. Mengingat proses audit kepatuhan terpadu melibatkan pula aparatur yang memiliki kewenangan dalam pengawasan lingkungan hidup sehingga mempunyai kewenangan dalam melakukan penegakan hukum administrasi. Hal tersebut selaras dengan tujuan penegakan hukum, khususnya

19 Dari 5 (lima) perusahaan perkebunan yang diaudit, 1 perusahaan tergolong sangat tidak patuh $(18,50 \%$ dari 97 kewajiban) dan 4 (empat) perusahaan tergolong tidak patuh (antara $23 \%$ sampai $48 \%$ dari 97 kewajiban). Lebih lanjut, Perusahaan Kehutanan : Dari 12 (tujuh belas) konsesi yang diaudit 1 (satu) konsesi perusahaan tergolong sangat tidak patuh $(7,22 \%$ dari 122 kewajiban), 10 (sepuluh) konsesi perusahaan tergolong tidak patuh (antara 26, $19 \%$ sampai 47, $54 \%$ dari 122 kewajiban) dan 1 (satu) konsesi perusahaan tergolong kurang patuh (52, $38 \%$ dari 122 kewajiban).

20 Tim Audit Kepatuhan Terpadu, op.cit., hlm. 6-7.

21 Lihat Nick Tilley dan Aiden Sidebottom terkait Theory for Crime Prevention dalam Nick Tilley dan Aiden Sidebottom (ed). Handbook of Crime Prevention and Community Safety. (London dan New York: Routledge, 2017) hlm. 8-10

22 Indonesia (a), op.cit., ps. 76 dan ps. 77 
dalam tujuan untuk mendorong kepatuhan sesuai pendapat Albert Reiss Jr., yaitu:

"Compliance and deterrence strategies of law enforcement have different objectives.

The principal objective of compliance law enforcement is to secure conformity with law by resorting to means that induce conformity or by taking actions to prevent law violations without the necessity of detecting, processing, and penalizing violators. The principal objective of deterrence law enforcement is to secure conformity with the law by detecting violations of the law, determining who is responsible for the violations, and penalizing violators to inhibit future violations by those who are punished and to inhibit those who might be inclined to violate the law if violators were not penalized. There are two principal types of compliance strategies of law enforcement, one based on incentives to comply, and the other on threats to invoke penalties for noncompliance unless actions to comply are taken. Compliance is voluntary in incentive-based systems whereas it is to some degree coerced in threat based systems." ${ }^{23}$

Sesuai pendapat Reis tersebut, bahwa terdapat perbedaan tujuan prinsip dari penegakan hukum yang berorientasi pada kepatuhan dan efek jera. Kepatuhan menekankan pada mendorong kepatuhan terhadap hukum dengan menggunakan sarana untuk mendorong kesesuaian hukum atau dengan mengambil tindakan untuk mencegah pelanggaran hukum tanpa keharusan menghukum pelaku melalui penghukuman yang menimbulkan efek jera melalui pemidanaan. Sedangkan, efek jera menekankan pada mendorong kepatuhan melalui proses penghukuman terhadap pelaku untuk mencegah kembali terjadinya pelanggaran hukum. Selain itu, meminimalisir kemungkinan pelaku untuk melakukan kejahatan. ${ }^{24}$ Tujuan penegakan hukum yang berorentasi pada kepatuhan adalah mengutamakan perlindungan lingkungan hidup dengan mendorong kepatuhan melalui pendekatan penegakan hukum administrasi, sebagaimana diungkapkan Mas Achmad Santosa, yaitu:

23 Albert J. Reiss Jr., Consequences Of Compliance And Deterrence Models of Law Enforcement For The Exercise of Police Discretion, Duke University School of Law Journal of Law and Contemporary Problems, Volume 47, No.4, (Durham: Duke University School of Law, 1984), hlm. 91-92

24 Brandon C. Welsh dan David D Farrington, Crime Prevention and Public Policy dalam The Oxford Handbook of Prevention. (New York: Oxford University Press, 2011), hlm. 4 
"Diskusi mengenai teori/argumentasi pendekatan compliance versus deterrence ini menghasilkan sebuah kesimpulan bahwa dalam konteks perlindungan dan pengelolaan lingkungan hidup, pendekatan compliance harus lebih diutamakan dibandingkan dengan pendekatan deterrence... Oleh sebab itu, pendekatan ultimum remedium (pendekatan penegakan hukum administrasi didahulukan sebelum diterapkan penegakan hukum pidana) yang dipersyaratkan oleh Pasal 100 UU No. 32 Tahun 2009 tentang PPLH merupakan pendekatan yang sudah benar dan tepat."25

Ketiga, pemetaan akar permasalahan dan perumusan kebijakan. Pelaksanaan audit kepatuhan terpadu juga dapat dikembangkan untuk memahami akar permasalahan dari kebakaran hutan dan lahan. Hasil observasi yang dilakukan di lapangan dan interaksi dengan pemangku kepentingan dapat menghasilkan data dan informasi yang relevan dalam memahami akar permasalahan kebarakan hutan dan lahan. Sebagai contoh, pada audit kepatuhan terpadu kebakaran hutan dan lahan tahun 2014, beberapa akar persoalan yang muncul karena kebijakan perlindungan lahan gambut tidak memadai, perencanaan tata ruang bermasalah, konflik agraria yang terkait dengan kebakaran, komitmen korporasi yang rendah dalam menyediakan sarana dan prasarana pencegahan, sampai dengan sarana Pembukaan Lahan Tanpa Bakar (PLTB) oleh pemerintah daerah yang belum jadi prioritas. ${ }^{26}$ Persoalan-persoalan tersebut menghasilkan 9 (sembilan) rekomendasi, yaitu: 1) perbaikan kebijakan perlindungan di kawasan rawan kebakaran baik dari hulu sampai hilir; 2) evaluasi konsensi korporasi didasarkan kesanggupan korporasi dalam menjaga kawasannya; 3) Penguatan Kapasitas Pemerintah Daerah dalam Resolusi Konflik; 4) penguatan sistem informasi karhutla; 5) penguatan legislasi khususnya terkait pedoman kewajiban pencegahan kebakaran hutan dan lahan; 6) penguatan pengawasan berjenjang melalui optimalisasi pengawas daerah; 7) pemberdayaan Masyarakat sekitar korporasi oleh korporasi dalam pencegahan kebakaran; 8) Dukungan Pembukaan Lahan Tanpa Bakar (PLTB) dan Insentif Lain bagi Masyarakat yang tidak membakar; dan 9) dukungan alokasi anggaran yang memadai serta tepat sasaran dalam mencegah kebakaran hutan dan lahan. ${ }^{27}$

25 Mas Achmad Santosa, Efektivitas Penegakan Hukum Administrasi Dalam Perlindungan Dan Pengelolaan Lingkungan Hidup Di Indonesia: Studi Kasus Di Provinsi Jawa Tengah, (Jakarta: Universitas Indonesia, 2014) hlm. 73-74

26 Tim Audit Kepatuhan Terpadu, op.cit., hlm. 8-11.

27 Loc.cit., hlm. 12-15 
Pada tingkat korporasi, mendorong agar korporasi melakukan langkahlangkah perbaikan sebelum terjadinya kebakaran hutan dan lahan. Sebagai contoh, kewajiban perusahaan membangun menara dan mengatur tingkat ketinggian air dilahan gambut. Pada tingkat perumusan kebijakan, diharapkan pemerintah pusat dan daerah melakukan kebijakan tertentu, seperti evaluasi konsesi audit sehingga kebakaran hutan dan lahan dapat dicegah.

Berdasarkan ketiga manfaat tersebut, maka tergambarkan bahwa audit kepatuhan terpadu berperan dalam konteks pencegahan sekunder (mitigasi). Hal tersebut didasarkan beberapa alasan. Pertama, sebagaimana penjelasan pertama, potensi kebakaran hutan dan lahan terjadi hampir disetiap tahun. Langkah yang dilakukan adalah untuk mencegah agar keadaan rawan kebakaran tidak menjadikan kebakaran hutan dan lahan terjadi meluas karena adanya prilaku dari korporasi maupun pelaku lainnya. Kedua, sebagaimana peranan pertama dan ketiga, audit kepatuhan terpadu mampu memetakan resiko dari potensial pelaku korporasi maupun dari sisi tata kelola yang membuat kebakaran yang terjadi secara sistematis dan meluas sehingga dapat dilakukan pencegahan. Ketiga, data dan informasi tersebut digunakan untuk melakukan intervensi pemerintah baik berupa penegakan hukum administrasi, kebijakan tata kelola atau tindakan lainnya.

\section{Konsep Pertanggungjawaban Korporasi dan Pemenuhan Kepatuhan}

Dasar dari pelaksanaan audit kepatuhan adalah untuk mengukur kepatuhan korporasi dalam menjalankan kewajibannya dalam mencegah kebakaran di wilayah konsensinya. Pertanyaan selanjutnya adalah sejauh apa kewajiban korporasi dalam melakukan pencegahan. Untuk itu, konsep pertanggungjawaban korporasi ini menjadi hal penting untuk dapat mengetahui sejauh apa kewajiban yang harus dilaksanakan oleh korporasi sehingga akan menentukan pula ukuran kepatuhan dalam pelaksanaan audit kepatuhan terpadu.

Legislasi kehutanan mewajibkan perusahaan kehutanan untuk mencegah kebakaran di wilayah kerja sesuai izin yang diberikan. Hal tersebut sesuai dengan Undang-Undang Tentang Kehutanan (UU Kehutanan) ${ }^{28}$ sebagai berikut:

28 Indonesia (b), Undang-Undang tentang Kehutanan, UU No. 41 Tahun 1999, sebagaimana di- 
"Pemegang izin usaha pemanfaatan hutan sebagaimana dimaksud dalam Pasal 27 dan Pasal 29, serta pihak-pihak yang menerima wewenang pengelolaan hutan sebagaimana dimaksud dalam Pasal 34, diwajibkan melindungi hutan dalam areal kerjanya." 29

Kewajiban tersebut dijelaskan lebih lanjut bahwa:

"Kewajiban melindungi hutan oleh pemegang izin meliputi pengamanan hutan dari kerusakan akibat perbuatan manusia, ternak, dan kebakaran."

Apabila dihubungkan antara bunyi pasal dan penjelasan maka perusahaan kehutanan mempunyai kewajiban untuk melindungi areal kerjanya dari kebakaran hutan. Artinya korporasi mempunyai kewajiban untuk melakukan langkah-langkah dalam mencegah terjadinya kebakaran hutan dan lahan. Lebih lanjut, pada sisi pertanggungjawaban atas tidak terlaksananya kewajiban, terdapat penegasan mengenai pertanggungjawaban korporasi sebagaimana diatur dalam UU Kehutanan, sebagai berikut:

"Pemegang hak atau izin bertanggung jawab atas terjadinya kebakaran hutan di areal kerjanya" 31

Pengaturan tersebut meletakkan beban pertanggungjawaban atas terjadinya kebakaran di areal kerja korporasi kepada korporasi tanpa secara tegas mengatur perlunya pembuktian siapa yang melakukan pembakaran. Konsep yang sebenarnya mirip dengan konsep tanggung jawab seketika (strict liability). Walaupun pengaturan tersebut belum dapat dikategorikan sebagai tanggungjawab seketika (strict liability) karena tidak mengatur secara jelas bentuk pertanggungjawabannya apakah pidana, perdata atau administratif serta sejauh apa korporasi harus bertanggungjawab. Konsep stirict liability tersebut akan dibahas kemudian.

Oleh karena itu, UU Kehutanan menempatkan tanggungjawab korporasi tidak terbatas pada tindakan aktif dari korporasi untuk membakar wilayahnya, tetapi sikap pasif dengan tidak mencegah menjadikan korporasi bertanggungjawab.

ubah dengan UU Nomor 19 Tahun 2004 tentang Penetapan Peraturan Pemerintah Pengganti Undang-Undang Nomor 1 Tahun 2004 Tentang Perubahan Undang-Undang Nomor 41 Tahun 1999 tentang Kehutanan, LN No. 86 Tahun 2004, LN No. 29 Tahun 2004.

29 Ibid., ps. 48 ayat (3)

30 Ibid.

31 Ibid., ps. 49. 
Sebagai contoh: pertanggungjawaban bukan hanya untuk tindakan perusahaan untuk membuka kawasan (land clearing), tetapi temasuk juga sikap pasif (omission) untuk tidak melakukan tindakan pencegahan yang optimal sehingga terjadinya kebakaran. Hal tersebut menunjukan bahwa legislasi kehutanan melihat kewajiban korporasi pada keberhasilan dari melakukan pencegahan berbasis dampak (materil) yaitu memastikan tidak terjadinya kebakaran. Walaupun sudah menyediakan sarana dan prasarana pencegahan kebakaran hutan, korporasi tetap dapat dimintakan pertanggungjawaban apabila kebakaran terjadi sehingga upaya yang dilakukan oleh korporasi harus sedemikian rupa sehingga kebakaran tidak terjadi.

Pendekatan legislasi perkebunan memliki pendekatan yang berbeda. Hal tersebut sesuai Undang Undang No. 39 Tahun 2014 tentang Perkebunan (UU Perkebunan), ${ }^{32}$ yaitu:

“(1) Setiap Pelaku Usaha Perkebunan dilarang membuka dan/atau mengolah lahan dengan cara membakar. (2) Setiap Pelaku Usaha Perkebunan berkewajiban memiliki sistem, sarana, dan prasarana pengendalian kebakaran lahan dan kebun."33

Kewajiban dalam UU Perkebunan tersebut bersifat larangan membakar dalam melakukan pembukaan lahan (land clearing) serta kewajiban bagi korporasi untuk memiliki sistem, sarana dan prasarana pengendalian kebakaran lahan dan kebun sebagaimana UU Kehutanan. Selain itu, UU Perkebunan menyebutkan mengenai kewajiban perusahaan dalam melakukan pelestarian lingkungan tetapi tidak menjelaskan mengenai tanggungjawab korporasi ketika terjadi kebakaran diwilayahya. Legislasi terbatas pada kewajiban penyediaan sarana, prasarana, dan sistem tanggap darurat yang memadai untuk menanggulangi terjadinya kebakaran, sebagaimana berikut:

"Untuk memelihara kelestarian fungsi lingkungan hidup sebagaimana dimaksud pada ayat (1), sebelum memperoleh izin Usaha Perkebunan, Perusahaan Perkebunan harus: ... c. membuat pernyataan kesanggupan untuk menyediakan sarana, prasarana, dan sistem tanggap darurat yang memadai untuk menanggulangi terjadinya kebakaran." 34

32 Indonesia (c), Undang-Undang tentang Perkebunan, UU Nomor 39 Tahun 2014, LN No. 308 Tahun 2014, TLN No. 5613.

33 Ibid., ps. 56 ayat (1) dan (2).

34 Ibid., ps. 67 ayat (3). 
Ketentuan tersebut tidak mengatur secara tegas mengenai pembebanan pertanggungjawaban kepada korporasi apabila terjadi kebakaran pada areal kerjanya selama korporasi sudah menyediakan pencegahan kebakaran lahan dan kebun yang memadai, tanpa penjelasan lebih lanjut ukuran memadai. Hal tersebut berpotensimenimbulkan dua tafsir pada ukuran "memadai". Tafsir pertama, ukuran memadai dinilai dari keberhasilan sarana dan prasarana tersebut dalam mencegah kebakaran hutan dan lahan sehingga bersifat materil. Sedangkan, tafsir kedua, ukuran memadai mengikuti ukuran tertentu yang ditetapkan oleh pemerintah yang menyebabkan tafsirnya menjadi bersifat formil. Dampaknya adalah apabila ditafsirkan secara formil, selama perusahaan perkebunan sudah mengikuti ketentuan mengenai ukuran "memadai" yang diwajibkan oleh pemerintah dan terjadi kebakaran lahan dan kebun maka menurut ketentuan undang-undang perkebunan, perusahaan tidak dapat dimintakan pertanggungjawaban.

Kelemahan pendekatan UU Perkebunan tersebut terjawab dalam legislasi lingkungan hidup yang mengatur lintas sektor, mulai dari pertambangan, kehutanan sampai perkebunan. UU PPLH mengatur bahwa:

"Setiap orang yang melakukan usaha dan/atau kegiatan berkewajiban: a. memberikan informasi yang terkait dengan perlindungan dan pengelolaan lingkungan hidup secara benar, akurat, terbuka, dan tepat waktu; b. menjaga keberlanjutan fungsi lingkungan hidup; dan c. menaati ketentuan tentang baku mutu lingkungan hidup dan/atau kriteria baku kerusakan lingkungan hidup."35

Ketentuan tersebut mewajibkan korporasi untuk menjaga keberlanjutan fungsi lingkungan hidup dan menaati ketentuan tentang baku mutu lingkungan hidup dan/atau kriteria baku kerusakan lingkungan hidup. Lingkup kriteria baku mutu kerusakan lingkungan termasuk juga kebakaran hutan dan lahan. ${ }^{36}$ Pembebanan tersebut dipertegas dengan adanya pertanggungjawaban korporasi baik secara perdata, pidana maupun administratif. Untuk perdata, bahkan menggunakan pendekatan tanggungjawab seketika bersifat mutlak (strict liability), yaitu:

"Setiap orang yang tindakannya, usahanya, dan/atau kegiatannya menggunakan

B3, menghasilkan dan/atau mengelola limbah B3, dan/atau yang menimbulkan ancaman serius terhadap lingkungan hidup bertanggung jawab mutlak atas

35 Indonesia (a), op.cit., ps. 68.

36 Ibid., ps. 21 ayat (3). 
kerugian yang terjadi tanpa perlu pembuktian unsur kesalahan."37

Artinya apabila kebakaran hutan dan lahan terjadi di wilayah korporasi, korporasi dapat dimintakan pertanggungjawaban tanpa melihat siapa yang melakukan pembakaran. Konsep strict liability merupakan konsep pembebanan pertanggungjawaban tanpa pembuktian elemen kesalahan yang berangkat dari kebutuhan melindungi masyarakat dari kejahatan tertentu yang sulit pembuktiannya. Hal tersebut sebagaimana diungkapkan Richard G. Singer dan John Q. La Fond, sebagai berikut:

"The courts here relied on two main premises: (1) legislature were unrestrained in their ability to proscribe conduct and did not have to require mens rea (a jurisprudential philosophy known as legal positivism); (2) there was a compelling need to protect society, particularly minors, against such evils (sex, liquor, etc), and it was too hard to prove mens rea.

During the first half of the twentieth century, some courts applied these decisions to newly enacted "regulatory" statutes, such as those prohibiting... (3) environmental damage" 38

Pada pendekatan pidana, korporasi dapat dimintakan pertanggungjawaban apabila gagal dalam mencegah kebakaran hutan dan lahan sehingga menimbulkan dampak baik karena secara aktif membakar, mendiamkan kebakaran dan tidak melaksanakan kewajiban pencegahan (omission) ${ }^{39}$ maupun kelalaian $^{40}$. Hal tersebut mengingat bahwa kewajiban dalam pencegahan kebakaran merupakan kewajiban hukum (legal obligation) sehingga tidak dilakukannya pencegahan menjadikan perbuatan tersebut dapat digolongkan sebagai dengan sengaja tidak melakukan (omission). ${ }^{41}$ Di Indonesia, hal tersebut selaras, berdasarkan pertimbangan hakim agung dalam putusan PT Kalista Alam :

"...Bahwa dan segi kesalahan perusahaan tidak menyediakan sarana dan prasarana dapat dikategorikan dengan sengaja..."42

37 Ibid., ps. 88.

38 Richard G. Singer dan John Q. La Fond, Criminal Law: Examples and Explanations, Sixth Edition, (New York: Wolters Kluwer, 2013) hlm. 121

39 Indonesia (a), op.cit., ps. 98.

40 Ibid., ps. 99.

41 Richard G. Singer dan John Q. La Fond, op.cit., hlm. 39.

42 Putusan No. 1554 K/Pid.Sus/2015 dengan Terpidana PT Kalista Alam 
Melalui berbagai pendekatan berbagai undangan tersebut, terdapat kemiripan dari UU Kehutanan dan UU PPLH dalam melihat pertanggungjawaban korporasi dengan pertanggungjawaban yang bersifat materil. Perbedaan terdapat pada UU Perkebunan yang bersifat formil. Akan tetapi, sebagaimana penjelasan sebelumnya, UU PPLH menjadi rujukan utama karena mengatur secara lebih khusus dari berbagai legislasi yang khusus (systematische specialiteit) yaitu UU Perkebunan maupun UU Kehutanan karena kebakaran hutan dan lahan merupakan ranah secara dampak masuk dalam lingkup lingkungan hidup sehingga diutamakan dibandingkan kedua legislasi lain. Oleh karena itu, dapat disimpulkan bahwa pencegahan kebakaran hutan maupun lahan terhadap korporasi bersifat materil baik terhadap perkebunan maupun kehutanan karena adanya legislasi lingkungan hidup. Melalui pencegahan yang bersifat materil tersebut, korporasi diwajibkan untuk melakukan pencegahan yang memastikan tidak terjadinya kebakaran. Pedoman kewajiban pencegahan yang diterbitkan pemerintah hanya bersifat sebagai pedoman standar minimal. Apabila terdapat kondisi tertentu (lokasi, jenis tanah gambut dan lain-lain) dan berdasarkan analisis resiko korporasi diperlukan upaya lebih dari pedoman yang dibentuk pemerintah maka upaya tersebut harus dilakukan.

\section{Landasan Kewenangan Pelaksanaan Audit Kepatuhan Terpadu}

Dasar hukum dari kewenangan pemerintah dalam melaksanakan audit kepatuhan terpadu menjadi hal yang menarik dibahas, mengingat ketentuan yang spesifik mengenai hal tersebut secara spesifik tercantum dalam Peraturan Menteri Lingkungan Hidup dan Kehutanan tentang Pengendalian Kebakaran Hutan dan Lahan (Peraturan Menteri LHK tentang Pengendalian Kebakaran Hutan dan Lahan). ${ }^{43}$ Sedangkan, pelaksanaan audit kepatuhan terpadu pada tahun 2014 didasarkan pada keputusan Kepala Unit Kerja Presiden Bidang Pengawasan dan Pengendalian Pembangunan (UKP PPP) dengan merujuk pada UU PPLH. Berkaitan dengan hal tersebut, terdapat dua isu, yaitu: dasar hukum dari audit

43 Menteri Lingkungan Hidup dan Kehutanan, Peraturan Menteri Lingkungan Hidup dan Kehutanan Tentang Pengendalian Kebakaran Hutan dan Lahan, Permen LHK No. P.32/MenLHK/ Setjen/Jum.1/3/2016, ps. 105. 
kepatuhan terpadu sebagai instrumen pencegahan kerusakan lingkungan hidup dan tim terpadu yang melaksanakan audit kepatuhan terpadu tersebut.

Dasar hukum kewenangan pemerintah dalam melakukan audit kepatuhan terpadu didasarkan pada legislasi lingkungan hidup. Berdasarkan UU PPLH, Pemerintah mempunyai kewajiban sebagai berikut:

“(1) Pengendalian pencemaran dan/atau kerusakan lingkungan hidup dilaksanakan dalam rangka pelestarian fungsi lingkungan hidup.

(2) Pengendalianpencemaran dan/ataukerusakanlingkunganhidup sebagaimana dimaksud pada ayat (1) meliputi: a. pencegahan; b. penanggulangan; dan c. pemulihan.

(3) Pengendalian pencemaran dan/atau kerusakan lingkungan hidup sebagaimana dimaksud pada ayat (1) dilaksanakan oleh Pemerintah, pemerintah daerah, dan penanggung jawab usaha dan/atau kegiatan sesuai dengan kewenangan, peran, dan tanggung jawab masing-masing." 44

Sesuai dengan ketentuan tersebut, pemerintah memiliki kewajiban untuk melakukan pengendalian pencemaran dan/atau kerusakan lingkungan yang terdiri dari pencegahan, penanggulangan dan pemulihan. Untuk melaksanakan kewajiban tersebut baik pencegahan, penanggulangan dan pemulihan dilakukan melalui berbagai instrumen. Adapun instrumen-instrumen pencegahan tersebut terdiri dari:

"Instrumen pencegahan pencemaran dan/atau kerusakan lingkungan hidup terdiri atas: $a$. KLHS; b. tata ruang; c. baku mutu lingkungan hidup; d. kriteria baku kerusakan lingkungan hidup; e. amdal; f. UKL-UPL; g. perizinan; h. instrumen ekonomi lingkungan hidup; i. peraturan perundang-undangan berbasis lingkungan hidup; j. anggaran berbasis lingkungan hidup; $k$. analisis risiko lingkungan hidup; l. audit lingkungan hidup; dan m. instrumen lain sesuai dengan kebutuhan dan/ atau perkembangan ilmu pengetahuan." 45

Instrumen tersebut terdiri dari 12 (dua belas) instrumen yang secara spesifik ditentukan oleh undang-undang dan 1 (satu) instrumen yang dapat dikembangkan oleh pemerintah. Instrumen audit kepatuhan terpadu tidak menjadi salah satu

44 Indonesia (a), op.cit., ps. 13.

$45 \quad$ Ibid.,ps. 14 
instrumen yang secara spesifik disebutkan. Adapun, pengaturan yang ada hanyalah audit lingkungan hidup. Perbedaannya, pada sisi pelaksana, audit kepatuhan hanya dapat dilaksanakan oleh auditor lingkungan hidup yang dipekerjakan oleh perusahaan baik dengan dipilih oleh perusahaan atau dipilih oleh menteri apabila perusahaan tidak mau melakukan audit kepatuhan. ${ }^{46}$ Mengenai hal yang diaudit, terbatas pada cara pandang auditor lingkungan hidup tanpa melihat aspek lainnya yang terkait kebakaran hutan dan lahan secara komprehensif. Selain itu, pada beberapa kasus rawan terjadi konflik kepentingan karena dibiayai oleh perusahaan.

Peluang audit kepatuhan terpadu didasarkan dari turunan dari instrumen ke-13 (ketiga belas) dari berbagai instrumen pencegahan pencemaran dan/atau kerusakan lingkungan hidup, yaitu:

".. m. instrumen lain sesuai dengan kebutuhan dan/atau perkembangan ilmu pengetahuan."

Instrumen tersebut memungkinkan pemerintah untuk membentuk instrumen lain sesuai kebutuhan dan/atau perkembangan ilmu pengetahuan. Dari berbagai hasil penelitian secara ilmiah, audit kepatuhan terpadu dibutuhkan untuk melihat bukan hanya dari sudut pandang lingkungan hidup tetapi aspek lain lain, seperti: kebijakan, tata kelola, kepentingan ${ }^{47}$ dan konflik sosial. ${ }^{48}$ Hal tersebut berangkat dari kebutuhan dalam melihat persoalan kebakaran hutan dan lahan secara komprehensif baik untuk mendorong kepatuhan maupun perbaikan kebijakan.

Secara teoritis, bukan hanya normatif undang-undang, landasan ilmiah dari dilaksanakannya audit kepatuhan terpadu tersebut juga selaras dengan salah satu landasan dalam pembuatan suatu kebijakan publik sebagaimana disampaikan Ian Gouh. Secara teori, menurut Ian Gouh dengan mengutip hasil penelitian Richard Freeman dan elaborasi yang dilakukannya bahwa kebijakan pencegahan didasarkan dari dua pondasi utama. Pertama, pemahaman ilmiah terhadap penyebab dan efek serta kemungkinan untuk memprediksi (scientific understandings of cause and effect and the possibility of prediction). Audit kepatuhan terpadu berangkat dari kebutuhan

\section{$46 \quad$ Ibid., ps. 48-51}

47 Helena Varkkey. The Haze Pollutin Problem in Southeast: Palm Oil and Patronage Asia. (London and New York: Routledge, 2016) hlm 18

48 Charles Victor Barber, Forests, Fires and Confrontation in Indonesia, (IISD, 2002), Hlm.110 
audit dengan melihat aspek yang komprehensif sesuai ilmu pengetahuan sebagaimana penjelasan sebelumnya. Kedua, kebijakan pencegahan tersebut diduga mempunyai kapasitas oleh pemerintah dalam melakukan intervensi yang dapat dikontrol dalam kehidupan sosial (prevention policy presumes some capacity for controlled intervention by government in social life). ${ }^{49}$ Pengambilan kebijakan audit kepatuhan terpadu merupakan bagian dari intervensi dalam upaya mencegah kebakaran hutan dan lahan khususnya dalam fungsi pencegahan sekunder sebagaimana dibahas sebelumnya.

Selanjutnya, kewenangan untuk membetuk audit kepatuhan terpadu tersebut teratribusi ${ }^{50}$ kepada Pemerintah. Sesuai dengan UU PPLH, kata "Pemerintah" merujuk pada:

"Pemerintah pusat, yang selanjutnya disebut Pemerintah, adalah Presiden Republik Indonesia yang memegang kekuasaan pemerintahan Negara Republik Indonesia sebagaimana dimaksud dalam Undang-Undang Dasar Negara Republik Indonesia Tahun 1945."

Berdasarkan hal tersebut, Presiden mendapatkan atribusi kewenangan dari undang-undang untuk membentuk dan melaksanakan audit kepatuhan terpadu. Pada pelaksanannya, sesuai dengan Peraturan Presiden Tentang Penataan Tugas dan Fungsi Kabinet Kerja ${ }^{52}$ dan Peraturan Presiden Tentang Kedudukan, Tugas, dan Fungsi Kementerian Negara serta Susunan Organisasi, Tugas, Dan Fungsi Eselon I Kementerian Negara, Kementerian Lingkungan Hidup dan Kehutanan ${ }^{53}$ mempunyai tugas membantu Presiden dalam urusan lingkungan hidup dan kehutanan. Artinya Menteri Lingkungan Hidup dan Kehutanan mempunyai kewenangan dalam perumusan dan penetapan kebijakan di bidang lingkungan hidup yang dalam hal ini adalah audit kepatuhan terpadu. Kebijakan tersebut

49 Ian Gough (a), op.cit, hlm.3

50 Philupus M. Hadjon, Fungsi Normatif Hukum Administrasi Dalam Mewujudkan Pemerintahan Yang Bersih, Pidato Peresmian Penerimaan Jabatan Guru Besar Dalam Ilmu Hukum Pada Fakultas Hukum Airlangga., 1994, hlm. 7

51 Indonesia (a), op.cit., ps. 1 angka 37

52 Presiden RI (a), Peraturan Presiden tentang Penataan Tugas Dan Fungsi Kabinet Kerja, Perpres Nomor 165 Tahun 2014, ps. 5

53 Presiden RI (b), Peraturan Presiden tentang Kedudukan, Tugas, Dan Fungsi Kementerian Negara Serta Susunan Organisasi, Tugas, Dan Fungsi Eselon I Kementerian Negara, Perpres No. Nomor 24 Tahun 2010, ps. 574 dan ps. 575. 
dibentuk dalam Peraturan Menteri LHK tentang Pengendalian Kebakaran Hutan dan Lahan.

Kesimpulannya, dasar kewenangan dalam pelaksanaan audit kepatuhan terpadu didasarkan pada kewenangan pemerintah dalam membentuk instrumen pencegahan (sebagai instrumen ke-13 (tiga belas)) didasarkan pada UU PPLH. Sedangkan, pada tahap pelaksanaan diturunkan secara teknis dalam Peraturan Menteri KLHK tentang Pengendalian Kebakaran Hutan dan Lahan walaupun tidak mengatur secara detail bagamana tata cara pelaksanaannya secara detail.

\section{Prasyarat Pelaksanaan Audit Kepatuhan}

Terdapat beberapa prasyarat yang diperlukan dalam mewujudkan audit kepatuhan terpadu secara optimal. Prasyarat tersebut terbagai dalam dua isu utama, yaitu: tim terpadu dan perangkat yang digunakan untuk melakukan audit. Tim terpadu terkait dengan kemampuan tim dalam melakukan indentifikasi persoalan dan pengukuran kepatuhan secara objektif, independen, komprehensif dan akuntabel. Sedangkan, perangkat yang digunakan adalah instrumen yang digunakan sebagai panduan dan ukuran kepatuhan dari objek yang diaudit.

Tim terpadu yang berintegritas dan profesional memiliki fungsi penting dalam melakukan audit kepatuhan. Untuk memenuhi hal tersebut dibutuhkan pemenuhan beberapa syarat. Pertama, tim terpadu harus didasarkan dari keterpaduan keahlian dan kewenangan yang relevan dengan sektor yang mempengaruhi pencegahan kebakaran hutan dan lahan. Pelibatan ahli dari universitas maupun lembaga riset yang menguasai bidang ilmunya memiliki fungsi penting untuk dilibatkan sehingga proses audit kepatuhan dilakukan secara ilmiah dan menggunakan metode yang tepat. Sebagai contoh, pada audit kepatuhan terpadu tahun 2014, terdapat ahli yang memahami kebakaran hutan dan lahan, kerusakan tanah dan hukum lingkungan hidup. ${ }^{54}$ Lebih lanjut, kewenangan dari Kementerian/Lembaga

54 Sesuai dengan Dokumen Audit Kepatuhan dalam Rangka Pencegahan Kebakaran Hutan dan Lahan, ahli yang digunakan antara lain: Bambang Hero Saharjo, ahli kebakaran hutan dan lahan, serta Basuki Wasis, ahli kerusakan tanah dari Institut Pertanian Bogor (IPB) memiliki peran penting dalam membangun instrumen audit sehingga audit dapat dilaksanakan sesuai dengan metode ilmiah. Hal tersebut diperkuat dengan tersedianya masukan pemenuhan sesuai legislasi yang berlaku dari Mas Achmad Santosa yang saat itu sekaligus 
yang dilibatkan memiliki fungsi penting sehingga temuan-temuan tersebut dapat ditindaklanjuti sesuai kewenangannya. Sebagai contoh, pada audit kepatuhan terpadu tahun 2014, pelibatan perwakilan dari Kementerian Lingkungan Hidup, Kementerian Kehutanan dan Kementerian Perkebunan memiliki peran untuk mendukung fleksibilitas pelaksanaan audit terkait kewenangan yang melekat padanya serta dukungan data serta informasi pendukung, seperti Amdal atau UKL-UPL, yang dimiliki kementerian tersebut. Ke depan, perlu dipertimbangkan pelibatan Kementerian Dalam Negeri karena memiliki kewenangan terkait pemerintah daerah yang menjadi mitra sekaligus objek audit kepatuhan terpadu.

Kedua, integritas dan indepedensi pelaku audit. Menjadi hal penting bagi tim audit untuk menghindarkan diri dari benturan kepentingan (conflict of interest). Benturan kepentingan tersebut dapat terjadi dari 2 (dua) pendekatan. Pendekatan pertama adalah pembiayaan. Pembiayaan yang dilaksanakan untuk mendukung proses audit seharusnya harus bebas dari pembiayaan oleh korporasi dengan tujuan menghindari konflik kepentingan. Apabila dikarenakan kondisi harus menggunakan sarana korporasi, seperti pada kondisi audit yang dilakukan melalui kanal dimana hanya korporasi yang memiliki kapal maka sedapat mungkin biaya penggunaan kapal tetap dibayarkan oleh tim audit kepatuhan terpadu. Pendekatan kedua adalah interaksi dengan objek audit kepatuhan dan kepentingan dari kementerian/lembaga yang terlibat. Sebagai contoh, Kementerian Kehutanan memiliki kewenangan dalam penerbitan izin dan mempunyai kepentingan dalam mendorong industri kehutanan untuk dapat meningkatkan produksi. Di sisi lain, Kementerian Kehutanan memiliki kewenangan untuk melakukan penegakan hukum atas pelanggaran yang terjadi. Untuk itu, menjadi penting untuk melibatkan Direktorat Jenderal yang melakukan pengawasan dan penegakan hukum administratif apabila audit melibatkan Direktorat Jenderal yang mendukung pelaksanaan produksi dari industri kehutanan. Hal tersebut untuk memastikan adanya masukan yang berimbang. Pada konteks ahli, pembacaan rekam jejak ahli yang terlibat menjadi penting khususnya terkait interaksi dengan korporasi. Hal tersebut untuk memastikan audit dilaksanakan secara berintegritas.

menjabat sebagai pengarah tim audit sekaligus Deputi Unit Kerja Presiden Bidang Perencanaan dan Pengawasan Pembangunan (UKP PPP) dan ahli hukum lingkungan hidup dari Universitas Indonesia. 
Perangkat audit kepatuhan terpadu menjadi isu penting untuk memastikan metode dan proses audit dilaksanakan secara objektif baik ukuran kepatuhan maupun pemilihan objek audit. Perangkat audit kepatuhan harus dapat mencerminkan segala aspek terkait kebakaran hutan dan lahan secara komprehensip. Pada audit kepatuhan terpadu tahun 2014, audit dilakukan dengan menggunakan tiga pendekatan, yaitu: aspek sistem dan kelembagaan, aspek sarana prasarana dan sumber daya manusia serta aspek biofisik dan sosial kemasyarakatan.

Aspek sistem dan kelembagaan digunakan untuk mengukur kesiapan korporasi dalam membangun sistem yang digunakan untuk mencegah kebakaran hutan dan lahan. Sebagai contoh, keberadaan Standard Operating Procedure (SOP) dan pelaksanaan SOP tersebut secara teknis di lapangan sehingga tidak terbatas hanya dokumen. Sedangkan, kelembagaan digunakan untuk melihat kesiapan kelembagaan korporasi dalam mencegah dan menangani kebakaran hutan dan lahan, seperti: kesediaan unit khusus yang memastikan kepatuhan korporasi dalam mencegah kebakaran khususnya dalam membaca potensi rawan kebakaran baik terkait faktor alam (contohnya: musim kemarau) maupun bukan alam (contohnya: musim tanam serta masyarakat sekitar) serta kemampuan merumuskan langkahlangkah yang dilakukan berdasarkan pembacaan kondisi tersebut.

Aspek sarana prasarana digunakan untuk mengukur kesediaan sarana dan prasarana yang digunakan baik untuk mencegah maupun menanggulangi kebakaran yang terjadi. Sebagai contoh, kesediaan alat pemantau titik api, kesediaan sarana pemadam api dan keterbukaan akses untuk memadamkan api. Untuk itu, kewajiban dihimpun dari adanya kewajiban dalam regulasi dan komitmen dalam dokumen Amdal atau UKL-UPL.

Secara regulasi, standar sarana dan prasanana pencegahan dan penanggulangan kebakaran hutan dan lahan belum secara terpadu diatur dalam satu regulasi di Indonesia. Untuk itu, pada audit kepatuhan terpadu tahun 2014, kewajiban standar minimal sarana dan prasarana pencegahan kebakaran dihimpun dari sedikitnya 12 (dua belas) regulasi untuk bidang kehutanan ${ }^{55}$ dan 8 (delapan) regulasi bidang

55 Dasar hukum untuk bidang kehutanan tersebut: a. Peraturan Pemerintah No. 45 Tahun 2004 tentang Perlindungan Hutan; b. Peraturan Pemerintah No. 4 Tahun 2001 tentang Pengendalian Kerusakan dan atau Pencemaran Lingkungan Hidup yang Berkaitan dengan Kebakaran Hutan dan atau Lahan; c. Instruksi Presiden Republik Indonesia No. 16 Tahun 
perkebunan ${ }^{56}$. Berbagai regulasi tersebut yang menjadi dasar pembuatan standar kepatuhan audit. ${ }^{57}$

Untuk mengakomodir kebutuhan minimal sarana dan prasarana dengan didasarkan analisis resiko yang diturunkan pada komitmen masing-masing perusahaan dalam dokumen Amdal atau UKL-UPL korporasi tersebut. Hal tersebut didasarkan pada kondisi bentang alam konsesi yang berbeda-beda sehingga dokumen Amdal atau UKL-UPL menjadi media yang penting untuk memperkirakan resiko dari aktivitas korporasi dan memastikan komitmen

2011 tentang Peningkatan Pengendalian Kebakaran Hutan dan Lahan Presiden Republik Indonesia; d. Peraturan Menteri Negara Lingkungan Hidup No. 10 Tahun 2010 tentang Mekanisme Pencegahan Pencemaran dan/atau Kerusakan Lingkungan Hidup yang Berkaitan dengan Kebakaran Hutan dan/atau Lahan; e. Peraturan Menteri Kehutanan No. P.12/Menhut-II/2009 tentang Pengendalian Kebakaran Hutan; f. Keputusan Direktur Jenderal Perlindungan Hutan dan Pelestarian Alam No. 48/KPTS/DJ-VI/1997 tentang Sistem Komando Pemadaman kebakaran Hutan Direktur Jenderal Perlindungan Hutan dan Pelestarian Alam; g. Keputusan Direktur Jenderal Perlindungan Hutan dan Pelestarian Alam No. 243/KPTS/DJ-VI/1994 tentang Petunjuk teknis Pencegahan dan Penanggulangan Kebakaran Hutan di Areal Pengusahaan Hutan dan Areal Penanggulangan Lainnya; h. Keputusan Direktur Jenderal Perlindungan Hutan dan Pelestarian Alam No. 244/KPTS/DJ-VI/1994 tentang Petunjuk Teknis Pemadaman Kebakaran Hutan; i. Keputusan Direktur Jenderal Perlindungan Hutan dan Pelestarian Alam No. 245/ KPTS/DJ-VI/1994 tentang Prosedur Tetap Pemakaian Peralatan Pemadam Kebakaran Peralatan Pemadam Kebakaran Hutan; j. Keputusan Direktur Jenderal Perlindungan Hutan dan Pelestarian Alam No. 246/KPTS/DJ-VI/1994 tentang Petunjuk Pembuatan dan Pemasangan Rambu-Rambu Kebakaran Hutan; k. Keputusan Direktur Jenderal Perlindungan Hutan dan Pelestarian Alam No. 247/KPTS/DJ-VI/1994 tentang Petunjuk Standarisasi Sarana Pencegahan dan Penanggulangan Kebakaran Hutan; dan 1. Keputusan Direktur Jenderal Perlindungan Hutan dan Pelestarian Alam No. 248/KPTS/DJ/VI/1994 tentang Prosedur Tetap Pencegahan dan Penanggulangan Kebakaran Hutan.

56 Dasar Hukum Kerangka Audit Bidang Perkebunan: a. Undang-Undang No. 18 Tahun 2004 tentang Perkebunan; b. Peraturan Pemerintah No. 4 Tahun 2001 tentang Pengendalian Kerusakan dan atau Pedoman atau Pencemaran Lingkungan Hidup yang Berkaitan dengan Kebakaran Hutan dan/atau Lahan; c. Instruksi Presiden Republik Indonesia No. 16 Tahun 2011 tentang Peningkatan Pengendalian Kebakaran Hutan dan Lahan; d. Peraturan Menteri Negara Lingkungan Hidup No. 10 Tahun 2010 tentang Mekanisme Pencegahan Pencemaran dan/atau Kerusakan Lingkungan Hidup yang Berkaitan dengan Kebakaran Hutan dan/atau Lahan; e Peraturan Menteri Pertanian No. 19/Permentan/ OT.140/3/2011 tentang Persyaratan Perkebunan Kelapa Sawit Berkelanjutan Indonesia (Indonesian Sustainable Palm Oil/ISPO); f. Peraturan Menteri Pertanian No. 98 Tahun 2013 tentang Pedoman Perizinan Usaha Perkebunan; g. Peraturan Menteri Pertanian No. 47/ Permentan/OT.140/4/2014 tentang Brigade dan Pedoman Pelaksanaan Pencegahan serta Pengendalian Kebakaran Lahan dan Kebun; dan h. Pedoman Pengendalian Kebakaran Lahan dan Kebun Direktorat Perlindungan Perkebunan Direktorat Jenderal Perkebunan Kementrian Pertanian Tahun 2010.

57 Tim Audit Kepatuhan Pencegahan Kebakaran Hutan dan Lahan, Laporan Audit Kepatuhan Kebakaran Hutan dan Lahan di Provinsi Riau, (Jakarta: BP REDD+, 2014). 
korporasi untuk memenuhinya sehingga kerusakan lingkungan hidup dapat dicegah.

Mengenai sarana prasarana, menjadi catatan penting bahwa pemenuhan sarana prasarana sesuai regulasi tidak berarti korporasi dapat melepaskan diri dari pertanggungjawaban korporasi baik perdata maupun pidana apabila terjadi kebakaran. Hal tersebut didasarkan tanggungjawab korporasi dalam pencegahan kebakaran hutan dan lahan bersifat materil sesuai dengan pembahasan pada pertanggungjawaban pidana korporasi. Adapun, penggunaan standar regulasi dan Amdal atau UKL/UPL sebagai dasar audit adalah untuk menetapkan standar yang sama dalam proses audit kepatuhan terpadu.

Aspek Biofisik dan sosial kemasyarakatan digunakan untuk mengevaluasi persoalan dari kondisi biofisik dan sosial kemasyarakatan serta pengaruhnya terhadap kebakaran hutan dan lahan. Aspek biofisik melihat apakah aktivitas yang dilakukan oleh korporasi dilakukan di kawasan yang sesuai dengan legislasi yang berlaku. Sebagai contoh, pengukuran kedalaman gambut di dalam wilayah konsesi dihubungkan dengan kesesuaian legislasi perlindungan gambut serta perlindungan flora dan fauna.

Aspek sosial kemasyarakatan menilai potensi konflik yang terjadi disekitar konsesi. Kebakaran terkadang disebabkan oleh ketidakjelasan tata kelola kawasan serta pemberian konsesi yang menyebabkan konflik sehingga pembukaan lahan dengan menggunakan pembakaran terjadi di wilayah sengketa.

Berbagai instrumen tersebut dibentuk didasarkan pada pemikiran faktor-faktor yang berpengaruh terhadap kesiapan dalam pencegahan kebakaran hutan dan lahan. Selain itu, instrument-instrumen tersebut berperan untuk dapat memahami persoalan pencegahan kebakaran hutan dan lahan secara komprehensif.

Menjadi hal penting untuk memastikan seluruh aspek tersebut dihitung secara cermat melalui metode perhitungan yang terukur. Hal tersebut untuk memastikan terciptanya proses audit yang akuntabel dan adil antar perusahaan yang menjadi objek audit kepatuhan. 
Tabel 1. Contoh Bagian Hasil Perhitungan Pada Pelaksanaan Audit Kepatuhan 2014

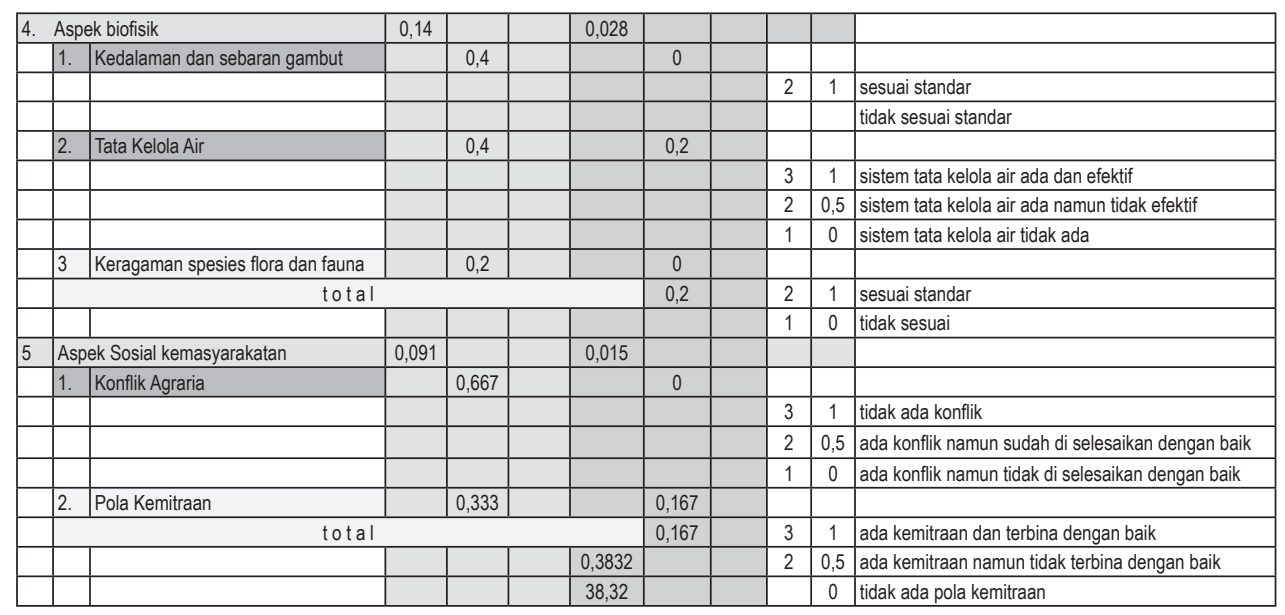

Penentuan objek audit memiliki peran penting juga untuk melaksanakan audit pada objek yang tepat. Hal tersebut untuk mendorong objek audit yang berpotensi terjadinya kebakaran dikonsesinya untuk patuh. Penentuan objek korporasi dan pemerintah daerah yang menjadi objek didasarkan pada pembacaan sejarah tingkat tingginya titik api maupun lokasi terbakar secara aktual. Hal tersebut untuk memastikan adanya lokasi yang tepat dalam melakukan audit kepatuhan.

\section{Penutup}

Audit kepatuhan terpadu yang dilaksanakan secara tepat dapat menjadi salah satu instrumen yang efektif dalam mencegah kebakaran hutan dan lahan. Hal tersebut terkait peran audit kepatuhan terpadu untuk mengukur kepatuhan korporasi, sehingga dapat ditindaklanjuti segara untuk memastikan korporasi memenuhi kewajibannya. Selain itu, audit kepatuhan terpadu berperan penting untuk menjadi dasar informasi dan data dalam kerangka penegakan hukum administrasi khususnya optimalisasi peran pengawasan pemerintah. Audit kepatuhan terpadu juga menjadi dasar untuk menemukan akar permasalahan sehingga dapat menjadi dasar perumusan kebijakan.

58 Tim Audit Kepatuhan Pencegahan Kebakaran Hutan dan Lahan, op.cit., hlm. 35. 
Untuk mendukung terciptanya audit kepatuhan terpadu, perlu dipenuhi prasyarat baik terkait dengan tim terpadu yang melaksanakan audit maupun instrumen yang digunakan sebagai acuan dalam pelaksanaan audit kepatuhan. Pemilihan objek audit dengan mempertimbangkan resiko maupun sejarah objek audit juga menjadi penting untuk membangun audit kepatuhan yang adil.

Ke depan, pelaksanaan audit kepatuhan sudah seharusnya dilaksanakan secara rutin dengan melibatkan berbagai pemangku kepentingan. Hal tersebut untuk memastikan upaya pencegahan kebakaran hutan dan lahan menjadi optimal serat memperkuat kapasitas pemerintah daerah dalam mencegah kebakaran hutan dan lahan. 


\section{DAFTAR PUSTAKA}

\section{Buku dan Tulisan}

Albert J. Reiss Jr. 1984. Consequences Of Compliance And Deterrence Models of Law Enforcement For The Exercise of Police Discretion, Duke University School of Law Journal of Law and Contemporary Problems, Volume 47, No.4. Durham: Duke University School of Law

Philupus M. Hadjon. 1994. Fungsi Normatif Hukum Administrasi Dalam Mewujudkan

Pemerintahan Yang Bersih, Pidato Peresmian Penerimaan Jabatan Guru Besar

Dalam Ilmu Hukum Pada Fakultas Hukum Airlangga.

Barber, Charles Victor. 2002. Forests, Fires and Confrontation in Indonesia. IISD

Departement of Environment and Conservation Team. 2006. Audit Compliance Handbook. NSW: DEC.

Sophie Martin. 2008. EPA Industry Compliance Audit Report for The Surface Coating Sector. Adelaide: EPA.

Tucker, J. and Bates, D.G (eds.). 2010. Human Ecology: Contemporary Research and Practice. New York: Spinger.

Nicholls QC, Colin et al. 2011. Corruption and Misuse of Public Office: Second Edition. Oxford: Oxford University Press.

Brandon C. Welsh dan David D Farrington (eds.). 2011. Crime Prevention and Public Policy dalam The Oxford Handbook of Prevention. New York: Oxford University Press.

Gough, Ian. 2011. Climate Change and Public Policy Futures, A Report Prepared for the British Academy. London: The British Academy.

Coote, A. 2012. The Wisdom of Prevention. London: nef.

Gough, Ian. 2013. Understanding prevention policy: A theoretical approach. London: London School of Economic and Political Science

Richard G. Singer dan John Q. La Fond. 2013. Criminal Law: Examples and Explanations, Sixth Edition. New York: Wolters Kluwer.

Mas Achmad Santosa. 2014. Efektivitas Penegakan Hukum Administrasi Dalam Perlindungan Dan Pengelolaan Lingkungan Hidup Di Indonesia: Studi Kasus Di Provinsi Jawa Tengah. Jakarta: Universitas Indonesia. 
Tim Audit Kepatuhan Terpadu. 2014. Ringkasan Eksekutif(Executive Summary) Audit Kepatuhan Dalam Rangka Pencegahan Kebakaran Hutan Dan Lahan Di Provinsi Riau. Jakarta: BP REDD+.

Tim Audit Kepatuhan. 2014. Laporan Lengkap Audit Kepatuhan Dalam Rangka Kebakaran Hutan dan Lahan di Provinsi Riau. Jakarta: BP REDD+.

Helena Varkkey. The Haze Pollutin Problem in Southeast: Palm Oil and Patronage Asia. (London and New York: Routledge, 2016)

Nick Tilley dan Aiden Sidebottom (eds.). 2017. Handbook of Crime Prevention and Community Safety. London dan New York: Routledge

https://www.soas.ac.uk/cedep-demos/000_P508_EAEMS_K3736-Demo/unit1/

page_14.htm diakses pada tanggal 24 Juli 2017

https://www.lapan.go.id/index.php/subblog/read/2014/838/KEKERINGAN-

TAHUN-2014-NORMAL-ATAUKAH-EKSTRIM/1653 diakses pada tanggal 3 Agustus 2017

https:// www.epa.gov/compliance/audit-protocols diakses pada tanggal 8 Juni 2017

\section{Peraturan dan Putusan}

Undang-Undang Nomor 41 Tahun 1999 tentang Kehutanan sebagaimana diubah dengan UU Nomor 19 Tahun 2004 tentang Penetapan Peraturan Pemerintah Pengganti Undang-Undang Nomor 1 Tahun 2004 Tentang Perubahan Atas Undang-Undang Nomor 41 Tahun 1999 Tentang Kehutanan Menjadi Undang-Undang

Undang-Undang No. 18 Tahun 2004 tentang Perkebunan

Undang-Undang Nomor 32 Tahun 2009 tentang Perlindungan dan Pengelolaan Lingkungan Hidup

Undang-Undang Nomor 39 Tahun 2014 tentang Perkebunan

Peraturan Pemerintah No. 4 Tahun 2001 tentang Pengendalian Kerusakan dan atau Pencemaran Lingkungan Hidup yang Berkaitan dengan Kebakaran Hutan dan atau Lahan

Peraturan Pemerintah No. 4 Tahun 2001 tentang Pengendalian Kerusakan dan atau Pedoman atau Pencemaran Lingkungan Hidup yang Berkaitan dengan Kebakaran Hutan dan/atau Lahan

Peraturan Pemerintah No. 45 Tahun 2004 tentang Perlindungan Hutan 
Peraturan Presiden Nomor 24 Tahun 2010 tentang Kedudukan, Tugas, Dan Fungsi Kementerian Negara Serta Susunan Organisasi, Tugas, Dan Fungsi Eselon I Kementerian Negara

Peraturan Presiden Nomor 165 Tahun 2014 tentang Penataan Tugas Dan Fungsi Kabinet Kerja

Instruksi Presiden Republik Indonesia No. 16 Tahun 2011 tentang Peningkatan Pengendalian Kebakaran Hutan dan Lahan .

Peraturan Menteri Kehutanan No. P.12/Menhut-II/2009 tentang Pengendalian Kebakaran Hutan.

Peraturan Menteri Negara Lingkungan Hidup No. 10 Tahun 2010 tentang Mekanisme Pencegahan Pencemaran dan/atau Kerusakan Lingkungan Hidup yang Berkaitan dengan Kebakaran Hutan dan/atau Lahan.

Peraturan Menteri Negara Lingkungan Hidup No. 10 Tahun 2010 tentang Mekanisme Pencegahan Pencemaran dan/atau Kerusakan Lingkungan Hidup yang Berkaitan dengan Kebakaran Hutan dan/atau Lahan

Peraturan Menteri Pertanian No. 19/Permentan/OT.140/3/2011 tentang Persyaratan Perkebunan Kelapa Sawit Berkelanjutan Indonesia (Indonesian Sustainable Palm Oil/ISPO)

Peraturan Menteri Pertanian No. 98 Tahun 2013 tentang Pedoman Perizinan Usaha Perkebunan

Peraturan Menteri Pertanian No. 47/Permentan/OT.140/4/2014 tentang Brigade dan Pedoman Pelaksanaan Pencegahan serta Pengendalian Kebakaran Lahan dan Kebun

Peraturan Menteri Lingkungan Hidup dan Kehutanan Nomor P.32/MenLHK/ Setjen/Jum.1/3/2016 Tentang Pengendalian Kebakaran Hutan dan Lahan Keputusan Direktur Jenderal Perlindungan Hutan dan Pelestarian Alam No. 243/KPTS/DJ-VI/1994 tentang Petunjuk teknis Pencegahan dan Penanggulangan Kebakaran Hutan di Areal Pengusahaan Hutan dan Areal Penanggulangan Lainnya

Keputusan Direktur Jenderal Perlindungan Hutan dan Pelestarian Alam No. 244/ KPTS/DJ-VI/1994 tentang Petunjuk Teknis Pemadaman Kebakaran Hutan. Keputusan Direktur Jenderal Perlindungan Hutan dan Pelestarian Alam No.245/KPTS/DJ-VI/1994 tentang Prosedur Tetap Pemakaian Peralatan Pemadam Kebakaran Peralatan Pemadam Kebakaran Hutan. 
Keputusan Direktur Jenderal Perlindungan Hutan dan Pelestarian Alam No. 246/KPTS/DJ-VI/1994 tentang Petunjuk Pembuatan dan Pemasangan Rambu-Rambu Kebakaran Hutan.

Keputusan Direktur Jenderal Perlindungan Hutan dan Pelestarian Alam No. 247/KPTS/DJ-VI/1994 tentang Petunjuk Standarisasi Sarana Pencegahan dan Penanggulangan Kebakaran Hutan.

Keputusan Direktur Jenderal Perlindungan Hutan dan Pelestarian Alam No. 248/KPTS/DJ/VI/1994 tentang Prosedur Tetap Pencegahan dan Penanggulangan Kebakaran Hutan.

Keputusan Direktur Jenderal Perlindungan Hutan dan Pelestarian Alam No. 48/KPTS/DJ-VI/1997 tentang Sistem Komando Pemadaman kebakaran Hutan Direktur Jenderal Perlindungan Hutan dan Pelestarian Alam.

Pedoman Pengendalian Kebakaran Lahan dan Kebun Direktorat Perlindungan Perkebunan Direktorat Jenderal Perkebunan Kementrian Pertanian Tahun 2010

Putusan No. 1554 K/Pid.Sus/2015 dengan Terpidana PT Kalista Alam 